\title{
Homeownership, Unemployment and Commuting Distances
}

\author{
Yuval Kantor \\ Peter Nijkamp ${ }^{1,2}$ \\ Jan Rouwendal,2
}

1 Faculty of Economics and Business Administration, VU University Amsterdam;

2 Tinbergen Institute. 
Tinbergen Institute is the graduate school and research institute in economics of Erasmus University Rotterdam, the University of Amsterdam and VU University Amsterdam.

More TI discussion papers can be downloaded at http://www.tinbergen.nl

Tinbergen Institute has two locations:

Tinbergen Institute Amsterdam

Gustav Mahlerplein 117

1082 MS Amsterdam

The Netherlands

Tel.: +31(0)205251600

Tinbergen Institute Rotterdam

Burg. Oudlaan 50

3062 PA Rotterdam

The Netherlands

Tel.: +31(0)10 4088900

Fax: $+31(0) 104089031$

Duisenberg school of finance is a collaboration of the Dutch financial sector and universities, with the ambition to support innovative research and offer top quality academic education in core areas of finance.

DSF research papers can be downloaded at: http://www.dsf.nl/

Duisenberg school of finance

Gustav Mahlerplein 117

1082 MS Amsterdam

The Netherlands

Tel.: +31(0)20 5258579 


\title{
Homeownership, Unemployment and Commuting Distances
}

\author{
Yuval Kantor \\ Peter Nijkamp* \\ Jan Rouwendal* \\ Department of Spatial Economics \\ VU University \\ De Boelelaan 1105 \\ $1081 \mathrm{HV}$ Amsterdam \\ The Netherlands \\ * Tinbergen Institute, The Netherlands
}

This version: February 9, 2012

\begin{abstract}
More than a decade ago Oswald has formulated the thesis that homeownership increases unemployment. Empirical research on micro data has confirmed that unemployed homeowners are less inclined to move house in combination with accepting a new job elsewhere. However, in general for European countries, residential mobility associated with unemployment spells appears to be too small to be able to have a substantial impact on labour market outcomes. The present paper aims to make a new contribution to the scientific debate on Oswald's thesis by addressing two complementary issues: risk attitudes of job seekers and commuting costs. We show that decreasing absolute risk aversion implies that the exit rate from unemployment is increasing in housing cost in the context of a standard job search model. In a spatial setting this is shown to imply that higher housing costs increase average commuting distances as well. We test these predictions on Dutch register data. Our empirical results show that outright homeowners have lower exit rates from unemployment than renters and are more reluctant to accept long commutes, which confirms Oswald's thesis. However, highly leveraged homeowners have higher exit rates than renters and are more inclined to accept longer commutes, which confirms earlier findings in the literature.
\end{abstract}

Key words: homeownership, unemployment duration, spatial labour markets JEL codes: J6, R2 
Pn551jkjr 


\section{Introduction}

The relationship between homeownership and unemployment is an intriguing one. According to Oswald's thesis ${ }^{1}$ there is a positive correlation between the two: a 10 percentage points increase in the share of homeowners is associated with a 2 percentage points increase in unemployment. A possible explanation of this is that homeowners are more reluctant to move to other regions in response to changing labour markets. It is entirely plausible that homeownership hampers residential mobility, and may therefore complicate finding a new job after becoming unemployed. Some microeconometric investigations have confirmed that residential mobility related to job search of unemployed workers is lower among homeowners, but have nevertheless found exactly the opposite of Oswald's thesis: homeowners tend to find a job faster than otherwise comparable renters after they become unemployed (Munch et al., 2006 for Denmark; Battu et al., 2008 for the UK; van Vuuren, 2008 for the Netherlands).

The explanation of this finding is that homeowners more often accept a job on the local labour market than renters do, whereas the reverse is true on the national labour market. The latter effect is in accordance with Oswald's thesis. However, the former effect dominates, as a common finding of the empirical work is that residential mobility related to job mobility is very limited. For instance, Munch et al. (2006) report that only $1.2 \%$ of the unemployment spells in their data end with employment in a distant labour market. ${ }^{2}$ This is true for renters as well as for owners in Denmark, the United Kingdom and the Netherlands, and probably in other European countries as well.

The low rates of residential mobility challenge any attempt to explain the correlation between homeownership and unemployment on the basis of differences between renters and owners in their propensity to accept a non-local job. At least in European countries, residential mobility associated with finding a new job (of renters as well as owners) is simply too uncommon to make a real difference in regional or national unemployment rates (see also Van den Berg and Gorter, 1997; as well as from a theoretical perspective Van Ommeren et al., 2000).

This does, of course, not exclude the possibility that there are other links between the housing and labour markets that are - at least potentially - quite important. In fact, the empirical findings reported in the literature may well be interpreted as pointing to other

\footnotetext{
${ }^{1}$ See Oswald $(1996,1997,1999)$

${ }^{2}$ Munch et al. (2006) p. 998. See also their footnote 5.
} 
issues. A repeated empirical finding is that the overall exit rate from unemployment among homeowners is found to be higher than among renters, whereas standard search models, in which searchers maximize lifetime utility in a stationary environment, predict that a tighter constraint on residential mobility, such as higher moving costs, will only partly be compensated by more intensive search on the local market, a lower reservation wage or acceptance of longer commutes. These models therefore predict that in the optimal strategy the overall exit rate from unemployment should still be lower among homeowners. They explain the observed higher exit rates of homeowners on the local labour market, but not the higher overall exit rate that is also present in the data, as was pointed out by Van Vuuren (2008). The higher overall exit rate of homeowners can only be explained by extending the model in such a way that homeowners differ from renters in other ways than just by the cost of residential mobility. Put differently: the relationship between homeownership and unemployment appears to be more complicated than is suggested by the model used by, for instance Munch et al. (2006) to motivate their empirical work. Following this line of thought, Van Vuuren (2008) developed a non-stationary search model to reconcile theory with the empirical facts. In his model long unemployment durations imply the risk of being forced to sell the house.

An alternative possibility to reconcile the theory with the empirical facts was suggested by Rouwendal and Nijkamp (2010) who developed a model in which search intensity depends on the value of income-net-of-housing-cost, the latter being fixed in the short run. This model is consistent with higher exit rates from unemployment among homeowner, if their income-net-of-housing payments are lower than that of otherwise comparable renters. The authors show this to be the case for the Netherlands, but do not provide an analysis of unemployment durations. Earlier, Flatau et al. (2003) presented empirical work for Australia that suggested that mortgage payments could provide important incentives for job search. In particular, they showed that highly leveraged male workers were more likely soon to find a job than outright owners.

Svarer et al. (2005) showed that rent control could have a substantial increasing effect on unemployment durations as the effects of the loss of the subsidy implied by moving are similar to that of higher moving costs among homeowners. Although residential mobility related to unemployment is quite small among renters as well, such subsidies are usually 
means-tested, which implies that they partly compensate for the income loss associated with unemployment and this may have an impact on the exit rates from unemployment. ${ }^{3}$

The connection between homeownership, unemployment and commuting is also policy relevant, as in many countries homeownership is encouraged (for instance by the tax deductibility of mortgage interest payments). Thus Oswald's thesis prompts questions of both policy and research nature, as is also witnessed in studies by Coulson and Fisher (2009) and Green and Hendershott (2001).

The present paper provides an investigation of unemployment duration in which housing tenure, mortgage payments and rent subsidies are all taken into account. In our model the higher exit rates from unemployment of searchers with high housing costs are related to decreasing absolute risk aversion, which is widely believed to be a realistic property of human behaviour under risk.

Although the relationship between accepting a job and residential mobility is empirically of limited importance, other spatial aspects of the labour market are interesting to study. It is a well known empirical fact that homeowners have longer commutes than renters, and a version of the labour market search model that incorporates commuting distances could provide an explanation for this finding. Munch et al. (2006) provide a brief discussion of this possibility, but they do not pursue this issue further. We take it up here.

The paper is organized as follows. In the next section we develop a job search model in a spatial labour market setting. Sections 3 and 4 describe the data and the econometric model used in the empirical analysis, the results of which are presented in section 5. Section 6 provides a discussion and concludes.

\section{A Search Model for Labour Market and Tenure Choice Interactions}

\subsection{Job search and the exit rate}

We assume that job seekers have a utility function with housing characteristics $h$ (a vector) and other consumption $c$ (aggregated to a scalar composite with unit price equal to 1 ) as its arguments. The budget constraint is $y=c+p(h)$ where $y$ denotes (current) net income minus commuting cost and $p$ net out-of-pocket housing cost, which are a function of $h$. In the

\footnotetext{
${ }^{3}$ Mortgage interest deductibility can be regarded as a subsidy for homeowners, but their impact on unemployment duration differs. The size of this benefit implied by the deductibility depends on the marginal rate of income taxation. Since the drop in income associated with unemployment tends to lower this marginal rate, it implies a partial loss of the subsidy that reinforces the negative effect of unemployment on income-netof-housing-cost.
} 
next subsection we introduce the spatial dimension of the labour market. Tenure is included in $h$ and we allow workers to attach a value to owning over renting. Rents are allowed to be different from the out-of-pocket housing costs of similar owner-occupied housing. Mortgage characteristics are also included in $h$, as they are an important determinant of out-of-pocket housing cost. Throughout the paper we assume housing characteristics of unemployed job seekers to be predetermined and fixed. ${ }^{4}$ It is important to note that the model of the present paper does not assume a simple dichotomy between renters (with low housing costs) and owners (with high housing costs). Instead we allow high as well as low housing costs for both tenure types. Outright owners have very low out-of-pocket housing costs, whereas highly leveraged owners living in a similar house can have extremely high housing costs and this difference may have an important impact on their search behaviour when unemployed.

Assuming the utility function is additively separable, we can write the indirect utility function $v$ as:

$$
v=u_{1}(y-p(h))+u_{2}(h)
$$

This formulation implies that the marginal utility of the composite consumption good is independent of $h$. Although one can often easily criticize separability assumptions, the formulation in (1) has the clear advantage that it emphasizes that living in a nice house cannot compensate for one's need for food, clothing and other nondurables. An important implication of (1) is, therefore, that housing (the vector $h$, not housing cost $p$ ) has no impact on labour market search behaviour.

The function $u_{1}$ in this equation is assumed to be increasing, concave and twice differentiable. The Bellman equation for stationary job search is:

$$
\rho U=u_{1}(b-p(h))+\lambda \int_{y} \max \left\{\frac{u_{1}(y-p(h))}{\rho}-U, 0\right\} f(y) d y .
$$

In this equation, $U$ is the value of unemployment, $b$ is the unemployment benefit, $\lambda$ is the arrival rate of job offers, $\rho$ is the discount rate, and $f(y)$ is the density of the wages of offered jobs. The optimal search strategy is to accept the first offer with a wage that is at least equal to a critical value, the so-called reservation wage, which we denote as $y^{\text {res }}$. Solving for $U$ gives:

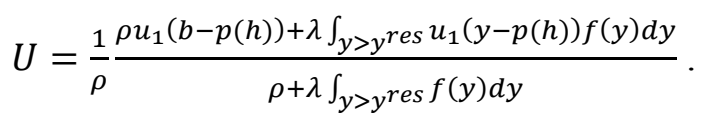

\footnotetext{
${ }^{4}$ The very low number of residential moves that we and others observe during unemployment spells confirm that this is a reasonable assumption.
} 
Maximizing the value of $U$ by choice of $y^{\text {res }}$ shows that $U^{\max }=u_{1}\left(y^{r e s}-p(h)\right) / \rho$. Substitution gives:

$$
u_{1}\left(y^{r e s}-p(h)\right)=\frac{\rho u_{1}(b-p(h))+\lambda \int_{y>y^{r e s}} u_{1}(y-p(h)) f(y) d y}{\rho+\lambda \int_{y>y^{r e s}} f(y) d y} .
$$

The exit rate from unemployment is equal to $\lambda \int_{y>y^{r e s}} f(y) d y$. It is increasing in housing cost if $\partial y^{\text {res }} / \partial p(h)<0$. It is shown in the Appendix that this is the case if the utility function $u_{1}$ has a property known as decreasing absolute risk aversion (DARA), which means that wealthier people are willing to pay less to escape an additional risk. ${ }^{5}$ This is widely regarded as a plausible characteristic of human behaviour. ${ }^{6}$

The analysis just presented implies that if DARA holds, workers with high housing cost have a higher exit rate from unemployment than otherwise comparable workers with lower housing cost. This analysis extends that in Rouwendal and Nijkamp (2010) who consider a model with variable search intensity but no variation in offered wage rates and assume that the utility function is quadratic. Moreover, it provides a theoretical underpinning of the results reported by Flatau et al. (2003) for Australia. In the empirical work presented below we will consider the relationship between housing cost and exit from unemployment for the Netherlands.

It may, finally, be noted that the combination of mortgage interest deductibility and marginal tax rates that an increase in income implies higher out-of-pocket housing costs after becoming unemployed. This reinforces the effect of DARA on labour market search. In contrast, a rent subsidy whose value depends on current income (or unemployment benefit) implies lower housing costs after becoming unemployed and therefore counteracts this effect.

\subsection{Implications for commuting}

To consider the implications of our model for commuting behaviour, we define $y$ as:

$$
y=w-t(r)
$$

where $w$ denotes net income and $t$ denotes commuting costs, which are an increasing function of the commuting distance $r$. Job offers are now random draws from a bivariate distribution of net wages and commutes. To show what the analysis of the previous section implies for the commutes of jobs accepted by job seekers, define $w^{r e s}$ as the lowest net wage that will

\footnotetext{
${ }^{5}$ Formally the property requires that $-u^{\prime \prime}{ }_{1} / u_{1}^{\prime}$ is decreasing.

${ }^{6}$ For instance, much empirical work in microeconomics assumes a utility function with constant relative tisk aversion, which implies decreasing absolute risk aversion. Empirical evidence in favor of this property can be found, for instance, in Chiappori and Paiella (2008).
} 
ever be accepted, that is $w^{r e s}=y^{r e s}$. A job offer with this wage will only be accepted when the implied commute is 0 . A job with commute $r$ will be accepted if the difference between net wage and commuting cost is equal to $y^{\text {res }}$ or larger, that is if:

$$
w \geq w^{r e s}+t(r) .
$$

If DARA holds, the reservation wage $w^{\text {res }}$ is a decreasing function of housing cost $p$, as previously noted. Figure 1 illustrates the impact of higher housing costs on the set of acceptable job offers when the commuting cost function is linear. In the figure it is assumed that $p_{1}<p_{2}<p_{3}$. The three upward sloping lines, which start at the reservation wages corresponding to the three housing costs, give the boundaries of the sets of acceptable combinations of wages and commuting distances corresponding to these housing costs. The sets of acceptable offers are indicated by the shading. As the picture shows, the set of acceptable wage-commute combinations shrinks when the housing cost is lower. This reflects the lower exit probabilities from unemployment: job seekers become more choosy when housing costs are less of a burden.

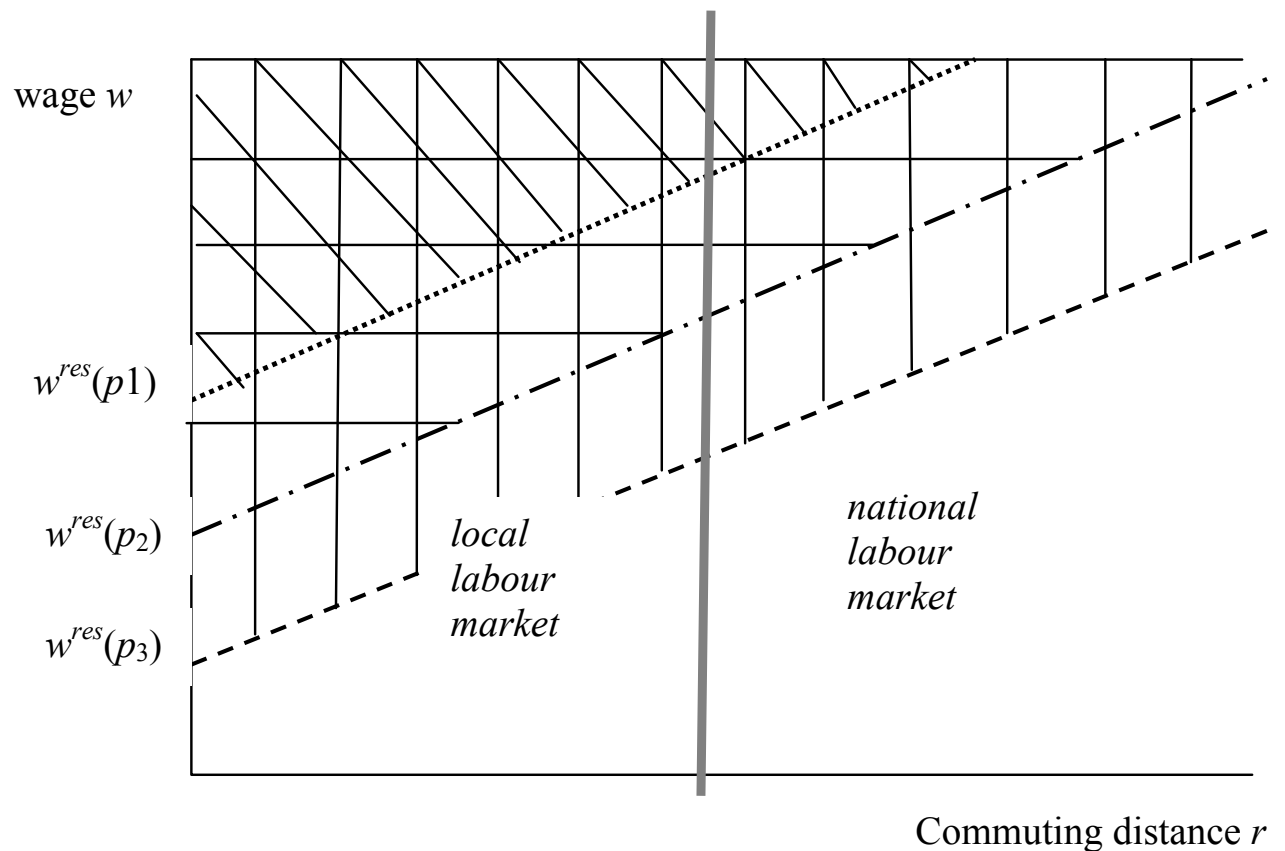

Figure 1. Acceptable wage offers and housing cost

The bold vertical line in Figure 1 indicates the limit of the local labour market. When housing costs decrease, acceptance probabilities for jobs on the local and national labour 
market both decrease. If homeowners have higher housing cost than renters, our model thus predicts that they have higher exit probabilities to the local as well as national labour markets.

The model also implies that outright owners, who have very low housing expenses will have lower exit rates from unemployment than otherwise comparable renters and owners with a (sizable) mortgage loan. The figure even suggests that with low housing costs the probability of accepting a job outside the local labour market may become negligible, although in the present model costs of residential mobility are absent. If confirmed by the empirical analysis, this could clearly be interpreted as confirming Oswald's thesis (see Flatau et al., 2003). On the other hand, if many owners are highly leveraged so that their out-ofpocket housing cost are higher than those of renters, the model would be consistent with the higher (average) exit rates from unemployment among homeowners observed by Munch et al. (2006).

It is important to observe that the model also suggests that higher housing costs imply that large commutes are accepted more frequently. To see this, consider the plausible situation in which net wages of jobs offered to a particular individual show very little variation. For simplicity, take the extreme case in which all offered jobs have the same wage rate. Then there is a critical commute that is an increasing function of the housing cost of this individual. The maximum, but also the expected commute is then a function of the housing cost. When there is variation in the net wages, the relationship is less straightforward, but a positive correlation between housing costs and commutes should still be expected. Job seekers that are in a rush to end unemployment are willing to accept jobs with low wages on the local labour market, but also jobs with not-so-low wages and long commutes.

\subsection{Other issues}

Like all models, ours is a simplification of reality and in this subsection we discuss some issues that we do not address explicitly. The main driving force behind our results is that high housing costs make the unemployed more eager to find a job. Housing costs are precommitted expenses and if one does not pay the mortgage or rent, sooner or later one has to leave the house. This means that priority has to be given to this expenditure, even if it means that little is left for daily expenses, so that finding a job becomes crucial. However, if people have enough resources to maintain a reasonably convenient level of consumption during an unemployment spell of limited length, this mechanism may not work. This suggests that our model may be less adequate for workers with relatively high levels of (non-housing) wealth that can be used to smooth consumption. Although the data we have do not inform us about 
wealth, we know that it is correlated with one's housing consumption and wage rate. More specifically, we expect owners without a mortgage to be in general more wealthy than comparable owners with a mortgage. For our empirical work this suggests that outright owners may differ more from those with a mortgage close to zero than would be suggested by the model developed above.

A second potentially important issue is that our model ignores the fact that net housing costs are often dependent on income. This is true for owners as well as for renters. The Netherlands has unlimited mortgage interest deductibility and a progressive income tax. Becoming unemployed may therefore imply a decrease in the tax rate and an increase in housing costs. Incorporating this effect into our model would increase the impact of housing costs of owners on the exit rates from unemployment. For renters the amount of rent subsidy received depends on one's income. A drop in income because of unemployment is partly compensated by an increase in the subsidy. Our model suggests that this will decrease the exit rates of renters from unemployment.

\subsection{Summary}

In this section we developed a job search model of the type conventionally used in labour market analysis. We introduced housing cost into the model and showed that for job seekers with decreasing absolute risk aversion the exit rate from unemployment must be increasing in housing cost. This prediction is an important contribution of the present paper and will be tested in the empirical analysis below. An important implication is that Oswald's thesis will hold unless the homeowners are so highly leveraged that their out-of-pocket housing costs exceed those of renters (as is found in the Netherlands by Rouwendal and Nijkamp, 2010).

Earlier analyses of Oswald's thesis have emphasized the spatial character of the labour market by distinguishing a local labour market and a national one. Jobs of the latter can only be accepted in combination with a change in the residential location. These models suggest that renters and owners behave quite differently on both markets. We have argued that actual residential mobility rates are too low to be of much significance for the overall unemployment figures. There is nevertheless a spatial dimension in our model: jobs with long commutes do not belong to the local labour market, but to the national one. We show that the predictions of our model for accepting jobs on the local and national labour markets are quite similar. Moreover, the model suggests a relationship between housing costs and commuting distances. 


\section{Data}

The data used in the analysis are unemployment spells of the Dutch population that began between 2000 and 2005, extracted from the Social Statistics Database (Sociaal Statistisch Bestand), which contains register data covering the whole Dutch population. An unemployment spell is defined as a period during which an individual has been receiving unemployment benefits. Consecutive periods of unemployment benefits with no more than three weeks separating them are considered as a single continuous period. Spells shorter than ten days are not considered, and spells longer than two years or with an unknown ending date are considered censored in the duration analysis.

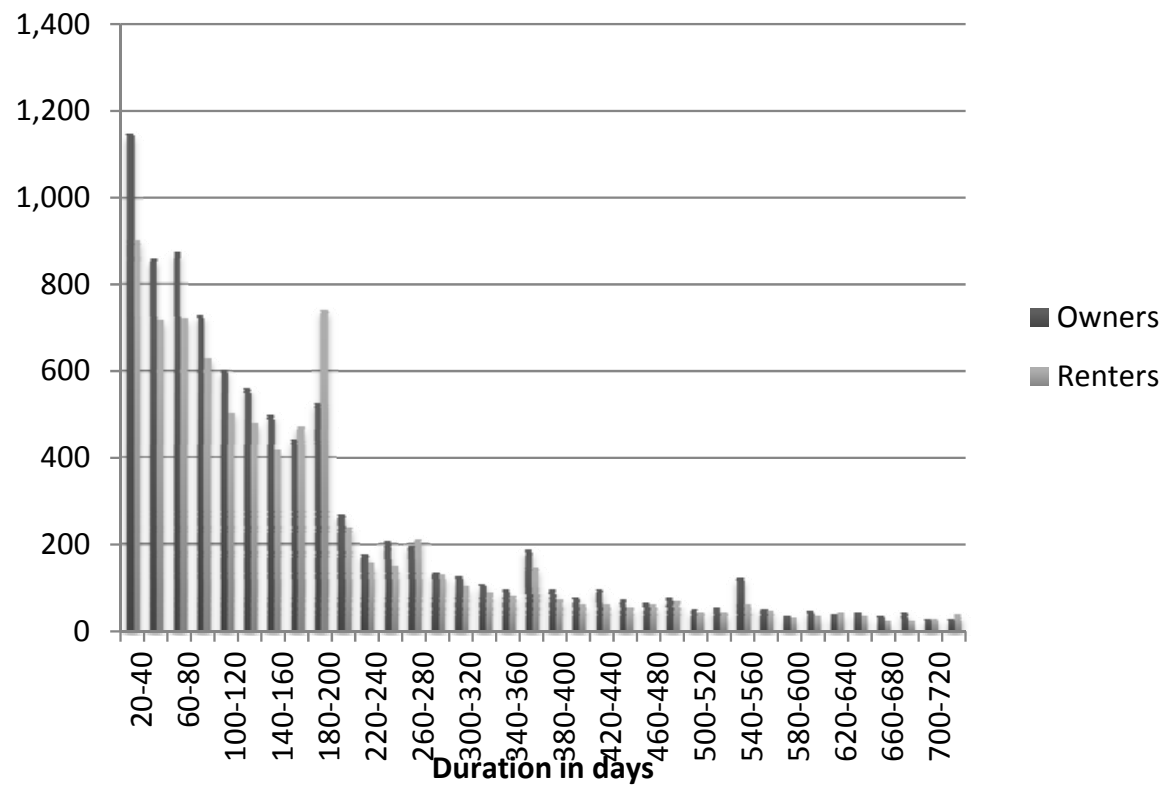

Figure 2. Histogram of unemployment spells duration

Several variables relevant to the analysis are merged from other data sources. The housing tenure status of the individuals is obtained from the Income Panel Register Database (Inkomenspanelonderzoek - IPO) for the relevant years, a dataset covering approximately $0.7 \%$ of the national population. The housing tenure status considered in the analysis is that which is observed at the time of one month before the unemployment spell ended. Figure 2 presents the duration distribution of the unemployment spells, distinguishing between homeowners and renters. The histogram generally declines with the increase in the duration 
of the spell. It does, however, feature peaks in cycles of half a year, owing to the Dutch system of unemployment benefits which were distributed in cycles of six months during the research period. The unemployed then has an incentive to remain jobless throughout the whole cycle of benefits eligibility. Additional variables obtained from the IPO database indicate the gross level of yearly mortgage interest costs (paid by homeowners) and the receipt of subsidies by renters.

For identifying unemployment spells that ended with employment and to extract the location of the workplace for determining the locality of the job and the commuting distance, information is gathered from the Social Statistics Databases of Jobs (Sociaal Statistisch Bestand Banen). Since (in the data) the start of an employment spell does not always immediately follow the end of its associated unemployment spell, any employment spell that started between one month before and two months after the end of the unemployment benefits spell is considered a job terminating the unemployment spell. The places of residence at various points in time surrounding the end of unemployment (eight weeks before, at the beginning, at the end, one year after) are gathered from the Municipal Administration Database (Gemeentelijke Basisadministratie), as well as other personal characteristics used as explanatory variables, of which two call for clarification. Native Dutch are individuals who were born in the Netherlands, and whose both parents were born in the Netherlands as well. Living in one of the four largest cities indicates living in Amsterdam, Rotterdam, Utrecht or The Hague. Table 1 presents descriptive statistics of the resulting set of unemployment spells.

The share of homeowners in our sample is close to the average in the Dutch population, but the share of homeowners with a mortgage (44\%) is considerably lower than the share of home-owning households with a mortgage in the Dutch population. The reason is that our data are based on tax records, which register the subtraction of mortgage interest paid from an individual's income. In two-earner households the two spouses can assign the mortgage interest paid by the households to either spouse. Naturally, they choose the one with the higher marginal tax rate, commonly the main earner of the household. His or her loss of a job is expected to have more significant consequences than a loss of a job of the spouse who does not subtract mortgage interest paid from taxable income. Our empirical analysis will therefore focus on the effects of having mortgage interest paid on one's individual income. 


\section{Table 1. Descriptive Statistics}

\begin{tabular}{|c|c|c|}
\hline \multicolumn{3}{|l|}{ Variable } \\
\hline Distance home-work after end of unemployment $(\mathrm{km})$ & 20.679 & 33.294 \\
\hline Homeownership & 0.565 & \\
\hline Age 19-24 & 0.132 & \\
\hline Age $25-29$ & 0.173 & \\
\hline Age 30-39 & 0.371 & \\
\hline Age 40-49 & 0.222 & \\
\hline Age $50+$ & 0.102 & \\
\hline Household with children & 0.669 & \\
\hline Female & 0.395 & \\
\hline Two adults household & 0.799 & \\
\hline Living in one of the four largest cities & 0.130 & \\
\hline Native Dutch & 0.741 & \\
\hline Share of homeowners with a mortgage & 0.439 & \\
\hline Annual out-of-pocket mortgage costs $(€ 1000 \mathrm{~s})$ & 3.764 & 6.141 \\
\hline Share of homeowners whose partner pays mortgage costs & 0.377 & \\
\hline Annual out-of-pocket partner’s mortgage costs $(€ 1000 \mathrm{~s})$ & 3.932 & 9.068 \\
\hline Share of renters receiving rent subsidies & 0.224 & \\
\hline $\begin{array}{l}\text { Number of spells ending without a move, } \\
\text { new job is up to } 45 \mathrm{~km} \text { far from home }\end{array}$ & 8,112 & \\
\hline $\begin{array}{l}\text { Number of spells ending without a move, } \\
\text { new job is farther than } 45 \mathrm{~km} \text { from home }\end{array}$ & 1,327 & \\
\hline Number of spells ending with a move & 215 & \\
\hline
\end{tabular}

Our data also inform us about mortgage interest subtracted on the spouses' taxable income. $38 \%$ of the homeowners has a spouse that does this, which implies that the total share of owner-occupying households with a mortgage is $82 \%$, which is close to the national average. ${ }^{7}$ This information also enable us to investigate the impact of having a spouse who subtracts paid mortgage interest from taxable income as will be discussed further below.

The mortgage payments reported in the table are gross payments. On average Dutch homeowners with a mortgage pay between $€ 300$ and $€ 400$ each month on mortgage interest. The data do not offer us a good approximation of the housing costs of renters or of the size of the unemployment benefit received.

Munch et al. (2006) define a job as non-local if the unemployed worker gets a job and moves to another of 51 Danish statistical "commuting areas". Van Vuuren (2008) defines a job as non-local, if it is not in same COROP region as the place of residence (there are 40 COROP regions in The Netherlands). Both studies conclude that homeowners find jobs more easily without an associated residential move, while renters have a higher chance of accepting

\footnotetext{
${ }^{7}$ Taking into account the fact that many elderly homeowners are outright owners, while our data refer to labor market participants, $82 \%$ is still lower than the national average. This can be interpreted as suggesting that outright owners are overrepresented in our data, This could clearly be consistent with Oswald's thesis.
} 
a job and moving. Nevertheless, as discussed in the introductory section, the low rates of residential mobility of both renters and homeowners in these studies raise serious doubts about the significance of mobility in determining labour market outcomes. In this paper too a very minor share of the unemployment spells end with a related change of residence. In our data, this share amounts to 215 spells out of a total of 10,256 . This number is simply too small to be of potential significance for explaining a difference in unemployment durations between renters and owners. Our empirical work will therefore focus on the spells which are not associated with a move.

We make a distinction between local and non-local according to the distance between the municipality of residence and the municipality in which the new workplace is located. This distance is measured between the geographic centres of the respective municipalities. Spells which ended in employment at workplaces, which are up to 45 kilometres far from the place of residence are considered local, while those that are further than $45 \mathrm{~km}$ are considered non-local. The sample is then composed of 8,112 spells which are local and 1,327 non-local. Spells that end without a transition into employment within two years of their beginning or ones that involve a change of residence, totalling 817 in number, are treated as censored.

The data inform us about the total net amount of mortgage interest paid by the worker (which is deductible from taxable income) and by the worker's partner, as well as about the level of rent subsidies they receive. We have no information about other mortgage costs (repayment) or cost of maintenance. Since mortgage interest is the major component of outof-pocket housing cost of homeowners with a mortgage, we can use it as a reasonable indicator of the housing cost of owners. However, the level of rent subsidy does not give an indicator of the housing cost of renters that is of comparable quality. The reason is that the rent subsidy is determined as much by the worker's income as by his rent. A relatively high rent subsidy can thus be caused by a high rent, but also by a low income (unemployment benefit). We do still expect the estimation results with respect to the rent subsidy to show the negative effect of the subsidy that is predicted by the theory, but we also expect these results to be more noisy than those with respect to mortgage interest paid. We therefore use only an indication of rent subsidies reliance rather than their reported levels.

\section{Econometric Model}

The duration analysis is conducted by means of a competing-risks mixed proportional hazard model with multiple spells. The potential endogeneity of homeownership choice is 
addressed by estimating the housing tenure status and the transitions out of unemployment simultaneously. This framework follows closely the model used by Munch et al. (2006), which, in turn, was based on the work of Van Leuvensteijn and Koning (2004).

The hazard rate of leaving unemployment, $\theta_{j}$, is the chance (or in our continuous case, density) of finding a job of type $j$ (either local or non-local) at time $t$ given that a job has not yet been found. It is composed of a baseline hazard $\lambda_{j}(t)$ scaled by an exponential function of the observed job searcher's characteristics $\mathbf{x}$, his home ownership state $z_{t}$ and unobserved characteristics $v_{j}$.

$$
\theta_{j}\left(t \mid \mathbf{x}, z_{t}, v_{j}\right)=\lambda_{j}(t) \exp \left(\boldsymbol{\beta}_{j}^{\prime} \mathbf{x}+\gamma_{j} z_{t}+v_{j}\right)
$$

The baseline hazard $\lambda_{j}(t)$ is given a piecewise constant specification, varying only between time intervals which are determined prior to estimation.

The possible endogeneity of homeownership is addressed by estimating the choice of housing tenure and the transitions out of unemployment simultaneously. The home ownership choice $z$ is modelled using a logit model, depending on observed and unobserved personal characteristics denoted by $\mathbf{x}$ and $v_{h}$ respectively.

$$
P\left(\mathbf{x}, v_{h}\right)=P\left(z=1 \mid \mathbf{x}, v_{h}\right)=\frac{\exp \left(\boldsymbol{\beta}_{h^{\prime}}^{\prime} \mathbf{x}+v_{h}\right)}{1+\exp \left(\boldsymbol{\beta}_{h^{\prime}}^{\prime}+v_{h}\right)}
$$

To identify and isolate the effect of homeownership, it is important that some individuals be observed in two or more unemployment spells and in particular that some individuals be observed as unemployed under different homeownership circumstances. Indeed, the sample used here contains 1432 individuals who experienced at least two unemployment spells, and 60 of them experienced at least one spell as a renter and another as a homeowner.

The complete likelihood function is given $b^{8}$

$$
\mathcal{L}=\iiint \prod_{m=1}^{M}\left\{\begin{array}{c}
P\left(x_{m}, v_{h}\right)^{z_{m}}\left[1-P\left(x_{m}, v_{h}\right)\right]^{1-z_{m}} \\
\theta_{l}\left(t \mid x_{m}, z_{t m}, c_{m}, v_{l}\right)^{d_{l m}} \theta_{n}\left(t \mid x_{m}, z_{t m}, c_{m}, v_{n}\right)^{d_{n m}} \\
\exp \left[-\int_{0}^{t} \theta_{l}\left(s \mid \mathbf{x}, z_{s m}, v_{l}\right) d s-\int_{0}^{t} \theta_{n}\left(s \mid \mathbf{x}, z_{s m}, v_{n}\right) d s\right]
\end{array}\right\} d G\left(v_{h}, v_{l}, v_{n}\right)
$$

where $x$ is a vector of observed individual characteristics and $v_{h}, v_{l}$ and $v_{n}$ denote unobserved characteristics, each taking one of two values and having a joint $c d f$ denoted by

\footnotetext{
${ }^{8}$ To correct for a misprint in Munch et al. (2006) and with the consent of its authors, the integral and product signs in the original equation were swapped.
} 
$G\left(v_{h}, v_{l}, v_{n}\right) . P$ is the probability of being a homeowner and is specified as a logit model. $z$ denotes the homeownership status at the end of the unemployment spell, $c$ is the size of the annual mortgage paid or rental subsidies received. The hazard rates of leaving unemployment after unemployment duration $t$ into the local and the non-local labour markets are denoted by $\theta_{l}$ and $\theta_{n}$ respectively, while $d_{l m}$ and $d_{n m}$ are dummies for the observed destinations at the end of the unemployment spell.

The main result of the analysis carried out in the previous sections is that DARA implies that a higher housing cost causes a higher exit rate from unemployment. This prediction was derived under the usual ceteris paribus condition and the previous wage and the unemployment benefit are important conditioning variables on which our data do not have information. However, we know from earlier research - notably Rouwendal and Nijkamp (2010) - that homeowners with a mortgage have on average an income net of housing cost that is lower than that of otherwise comparable renters. Since the unemployment benefit is dependent on the value of income earned before one becomes unemployment, the same will hold for unemployed workers, and the consequences of a lower income for mortgage interest deductibility and rent subsidy will reinforce the difference. The combination of mortgage interest deductibility and a progressive income tax will tend to increase the difference. This means that - although we do not know the exact value of the unemployment benefit, we can still be sure that the average homeowner with a mortgage has a lower income-net-of-housing cost than otherwise comparable renters and we expect them have a higher exit rate.

We expect that our lack of information about the unemployment benefit can have more serious consequences for the marginal impact of mortgage costs on the exit rate from unemployment. Housing demand, and consequently mortgage payments, are positively correlated with income. We therefore expect a positive correlation between the unemployment benefit (which is an increasing function of income) and mortgage payments. This makes it highly unlikely that the coefficient of the size of the mortgage payment that we measure can be interpreted as an unbiased estimate of the impact of higher mortgage payment on the exit rate from unemployment. It also picks up the effect of the higher unemployment benefit that results from the higher income that is usually associated with the higher housing and mortgage demand.

There is one other issue that should be discussed before we proceed to the estimation results. In households with two earners it is not the difference between the unemployment 
benefit and the mortgage payments that matters, but the difference between the sum of the unemployment benefit and the spouses' income and the mortgage payment. On the other hand, it must also be taken into account that the presence of two adults and possibly also children has an impact on the household's consumption needs that probably has an impact on job search. This means that it is important to control for household composition.

The discussion thus far refers to workers who subtract the mortgage interest paid from their taxable income. As we explained above, these are usually the main earners. Our data also allow us to look for a possible impact of mortgage interest that has been subtracted from the spouse's income. Within a household, couples commonly share financial responsibilities as well as the ownership of property. It is therefore reasonable to assume that labour search behaviour is also influenced by the leverage of one's partner. Although a very simple unitary model of household behaviour would perhaps predict the same impact of the leverage on these workers, we do not expect this to be the case. We would rather expect a smaller impact of the mortgage interest payments on these workers whose income is smaller than that of their spouse. Many Dutch women have a part time job and the difference between their income and that of the main earner is therefore often substantial. The fact that the household owns the house in which it lives may then reflect a high income of the spouse, rather than a low value of the income-net-of-housing-cost of the family. Similarly, higher mortgage payments may reflect a higher income of the spouse, who is usually still employed. Summarizing, the main hypothesis that we will test is that for a main earner, being a leveraged homeowner implies a higher exit rate from unemployment than being a renter, while for outright owners the reverse is true. We are agnostic with respect to the marginal impact of mortgage payments on the exit rate from unemployment and with respect to the impact of a mortgage on the labour market behaviour of secondary workers, who do not subtract mortgage payments from their taxable income.

\section{Results}

In this section the estimation results of the econometric model described above are presented. The unemployment duration analysis differentiates as competing risks between accepting a local job and accepting a non-local one. The former is defined as having an associated commute of less than 45 kilometres and the latter a commuting distance of 45 kilometres or more. The effects of modifying this threshold are reported at the end of this section. 
Table 2 shows the results of the hazard function as well as the simultaneously estimated homeownership selection. The first column lists the estimates of the $\beta$ vector of the hazard function for leaving unemployment to a local job and their respective standard error. Similarly, the second column lists the estimates and standard errors of the hazard function of leaving unemployment to a non-local job. The last column presents the estimates and standard errors of the homeownership selection equation.

The effect of homeownership on finding a local job is statistically insignificant. In contrast, homeownership significantly lowers the hazard of finding a non-local job by as much as $48 \%\left(e^{-0.645}-1\right)$. Since residential mobility associated with unemployment is negligible, this result cannot be exclusively explained by high moving costs. Still, homeowners are more reluctant than renters to accept non-local jobs. In contrast, being bound to mortgage return increases the local hazard rate, though this effect diminishes modestly with the size of mortgage payments, while the non-local hazard increases with the level of mortgage payments. To make the picture clearer, consider a homeowner with yearly mortgage costs of $€ 3,800$. His hazard of finding local employment is $e^{0.272} \cdot e^{-0.010 * 3.8}-$ $1=26 \%$ higher than that of an otherwise identical unleveraged homeowner, and his hazard of finding non-local employment is $59 \%$ higher. The housing subsidies received by renters reveal a negative and substantial effect on both local and non-local hazards.

Other variables have a rather expected impact on the hazard rates. The older the unemployed individual is, the lower is the hazard out of unemployment, and this effect is stronger on the local hazard than on the non-local hazard. Females have a moderately higher hazard of finding a job locally. The presence of children in the household exhibits a negative effect on the non-local hazard while females with children have a considerably lower hazard of finding employment of both types. Native Dutch individuals have higher risks out of unemployment compared to non natives, and living in a large city lowers the hazard of leaving unemployment to the non-local market. Workers belonging to two-adult households have a non-local hazard which is higher than that of workers belonging to single-adult households.

The homeownership selection covariates are all statistically significant. Individuals in their middle age are more likely to be homeowners, and so are two-adult households and residents of small cities. Females, households with children and native Dutch are also typically more likely to be homeowners. 
Table 2. Estimation results using individual's leverage

\begin{tabular}{|c|c|c|c|}
\hline & Local Hazard & Non-local hazard & $\begin{array}{l}\text { Homeownership } \\
\text { selection }\end{array}$ \\
\hline Homeownership & $\begin{array}{l}-0.163 \\
(0.087)\end{array}$ & $\begin{array}{r}-0.645^{*} \\
(0.193)\end{array}$ & \\
\hline Mortgage Dummy & $\begin{array}{l}0.272 * \\
(0.052)\end{array}$ & $\begin{array}{l}0.345^{*} \\
(0.120)\end{array}$ & \\
\hline $\begin{array}{l}\text { Yearly mortgage interest } \\
\text { payment }\end{array}$ & $\begin{array}{l}-0.010^{*} \\
(0.004)\end{array}$ & $\begin{array}{l}0.031^{*} \\
(0.008)\end{array}$ & \\
\hline Rental subsidies dummy & $\begin{array}{l}-0.102^{*} \\
(0.048)\end{array}$ & $\begin{array}{l}-0.333^{*} \\
(0.133)\end{array}$ & \\
\hline Age 19-24 & $\begin{array}{l}0.776^{*} \\
(0.053)\end{array}$ & $\begin{array}{l}0.416^{*} \\
(0.131)\end{array}$ & $\begin{array}{l}-1.946^{*} \\
(0.213)\end{array}$ \\
\hline Age $25-29$ & $\begin{array}{l}0.455^{*} \\
(0.045)\end{array}$ & $\begin{array}{c}0.197 \\
(0.112)\end{array}$ & $\begin{array}{l}-1.725^{*} \\
(0.194)\end{array}$ \\
\hline Age 30-39 & $\begin{array}{l}0.131^{*} \\
(0.035)\end{array}$ & $\begin{array}{l}0.140 \\
(0.087)\end{array}$ & $\begin{array}{l}-0.270^{*} \\
(0.135)\end{array}$ \\
\hline Age $50+$ & $\begin{array}{l}-0.263^{*} \\
(0.048)\end{array}$ & $\begin{array}{l}-0.233^{*} \\
(0.117)\end{array}$ & $\begin{array}{l}-0.408^{*} \\
(0.208)\end{array}$ \\
\hline Female & $\begin{array}{l}0.129^{*} \\
(0.039)\end{array}$ & $\begin{array}{l}-0.030 \\
(0.089)\end{array}$ & $\begin{array}{l}0.338^{*} \\
(0.156)\end{array}$ \\
\hline Household with children & $\begin{array}{c}0.055 \\
(0.047)\end{array}$ & $\begin{array}{l}-0.336^{*} \\
(0.119)\end{array}$ & $\begin{array}{l}0.395^{*} \\
(0.177)\end{array}$ \\
\hline Two adults household & $\begin{array}{l}-0.004 \\
(0.039)\end{array}$ & $\begin{array}{l}0.194^{*} \\
(0.093)\end{array}$ & $\begin{array}{l}3.083^{*} \\
(0.208)\end{array}$ \\
\hline Female $X$ children & $\begin{array}{l}-0.267^{*} \\
(0.058)\end{array}$ & $\begin{array}{l}-0.351^{*} \\
(0.146)\end{array}$ & $\begin{array}{l}0.484^{*} \\
(0.220)\end{array}$ \\
\hline Large city & $\begin{array}{l}-0.025 \\
(0.044)\end{array}$ & $\begin{array}{l}-0.304^{*} \\
(0.106)\end{array}$ & $\begin{array}{l}-1.557^{*} \\
(0.163)\end{array}$ \\
\hline Native Dutch & $\begin{array}{l}0.112^{*} \\
(0.034) \\
\end{array}$ & $\begin{array}{l}0.265^{*} \\
(0.084) \\
\end{array}$ & $\begin{array}{l}2.537^{*} \\
(0.182) \\
\end{array}$ \\
\hline \multicolumn{4}{|l|}{ Baseline Hazard } \\
\hline $0-45$ days & $\begin{array}{l}1.915^{*} \\
(0.167)\end{array}$ & $\begin{array}{l}0.757^{*} \\
(0.175)\end{array}$ & \\
\hline 46-91 days & $\begin{array}{l}2.515^{*} \\
(0.226)\end{array}$ & $\begin{array}{l}1.015^{*} \\
(0.233)\end{array}$ & \\
\hline $92-182$ days & $\begin{array}{l}3.135^{*} \\
(0.298)\end{array}$ & $\begin{array}{l}1.068^{*} \\
(0.244)\end{array}$ & \\
\hline 183-730 days & $\begin{array}{l}2.252^{*} \\
(0.232) \\
\end{array}$ & $\begin{array}{l}0.587^{*} \\
(0.142) \\
\end{array}$ & \\
\hline$v_{h, 1}$ & $\begin{array}{l}-0.067 \\
(0.194)\end{array}$ & $P\left(v_{h, 1}, v_{l, 1}, v_{n, 1}\right)$ & $\begin{array}{c}0.022 \\
(0.034)\end{array}$ \\
\hline$v_{h, 2}$ & $\begin{array}{l}-6.726^{*} \\
(0.338)\end{array}$ & $P\left(v_{h, 1}, v_{l, 1}, v_{n, 2}\right)$ & $\begin{array}{c}0.019 \\
(0.024)\end{array}$ \\
\hline$v_{l, 2}$ & $\begin{array}{l}-1.025^{*} \\
(0.063)\end{array}$ & $P\left(v_{h, 1}, v_{l, 2}, v_{n, 1}\right)$ & $\begin{array}{l}0.171^{*} \\
(0.029)\end{array}$ \\
\hline$v_{n, 2}$ & $\begin{array}{l}-2.408^{*} \\
(0.323)\end{array}$ & $P\left(v_{h, 1}, v_{l, 2}, v_{n, 2}\right)$ & $\begin{array}{l}0.086^{*} \\
(0.027)\end{array}$ \\
\hline $\operatorname{corr}\left(v_{h}, v_{l}\right)$ & $\begin{array}{c}0.093 \\
(0.111)\end{array}$ & $P\left(v_{h, 2}, v_{l, 1}, v_{n, 1}\right)$ & $\begin{array}{l}0.257^{*} \\
(0.035)\end{array}$ \\
\hline $\operatorname{corr}\left(v_{h}, v_{n}\right)$ & $\begin{array}{c}0.126 \\
(0.111)\end{array}$ & $P\left(v_{h, 2}, v_{l, 1}, v_{n, 2}\right)$ & $\begin{array}{l}0.166^{*} \\
(0.033)\end{array}$ \\
\hline $\operatorname{corr}\left(v_{l}, v_{n}\right)$ & $\begin{array}{l}-0.427^{*} \\
(0.167)\end{array}$ & $P\left(v_{h, 2}, v_{l, 2}, v_{n, 1}\right)$ & $\begin{array}{l}0.101 * \\
(0.031)\end{array}$ \\
\hline Log likelihood & -11654.1 & $P\left(v_{h, 2}, v_{l, 2}, v_{n, 2}\right)$ & $\begin{array}{l}0.178^{*} \\
(0.033)\end{array}$ \\
\hline
\end{tabular}

* indicates significance at the $5 \%$ level.

The standard error of the correlation terms were calculated using 1,000 random draws from a multivariate normal distribution with means and covariances of the estimated regression parameters (see Munch et al. 2006). 
The correlation terms of the unobservables ${ }^{9}$ can be used to examine whether people who are - for some unobserved characteristic - more likely to become homeowners are also more likely to accept long commutes. The insignificant estimates of the first two terms do not seem to support such a hypothesis. This is reassuring for our interpretation in which we attribute the longer commutes to the impact of the mortgage. It is suggested by the latter negative correlation term, though, that some unobserved characteristics has an opposite effect on both hazards.

Table 3 reports the empirical findings of a model incorporating the partner's mortgage payments. The results exhibit a milder negative effect of homeownership on the hazard out of unemployment. The positive effect of being bound to a mortgage on the transition into both types of employment diminishes as well, though it remains positive under typical levels of mortgage. The striking finding is that a leveraged partner is found to have a strong negative effect on the non-local hazard, decreasing it by more than $30 \%$. The other personal characteristics, baseline hazards and unobserved heterogeneity terms show similar estimates as in the model reported before.

In order to investigate the robustness of our results, we conducted a similar analysis using thresholds of 35 kilometres and 55 kilometres to make the distinction between the competing risks. The estimates of the housing costs coefficients hardly differ, and so are their levels of significance. The direct effect of homeownership does not change at the $35 \mathrm{~km}$ analysis, but when the $55 \mathrm{~km}$ threshold is used in the analysis which includes the leverage of the partner, the effect of homeownership on the non-local hazard is weakened to a statistically insignificant -0.254 (s.e. 0.259 ), as compared with -0.423 reported above.

\footnotetext{
${ }^{9}$ The standard errors of the unobserved heterogeneity terms are computed using 1,000 drawings from a multivariate normal distribution with mean and covariance based on the estimation results.
} 
Table 3. Estimation results considering the partner's leverage

\begin{tabular}{|c|c|c|c|}
\hline & Local Hazard & Non-local hazard & $\begin{array}{l}\text { Homeownership } \\
\text { selection }\end{array}$ \\
\hline Homeownership & $\begin{array}{l}-0.009 \\
(0.095)\end{array}$ & $\begin{array}{l}-0.423^{*} \\
(0.209)\end{array}$ & \\
\hline Mortgage Dummy & $\begin{array}{l}0.152^{*} \\
(0.061)\end{array}$ & $\begin{array}{c}0.090 \\
(0.146)\end{array}$ & \\
\hline $\begin{array}{l}\text { Yearly mortgage interest } \\
\text { payment }\end{array}$ & $\begin{array}{l}-0.009^{*} \\
(0.004)\end{array}$ & $\begin{array}{l}0.032^{*} \\
(0.008)\end{array}$ & \\
\hline Partner's Mortgage Dummy & $\begin{array}{l}-0.106 \\
(0.066)\end{array}$ & $\begin{array}{l}-0.351^{*} \\
(0.167)\end{array}$ & \\
\hline $\begin{array}{l}\text { Yearly partner's mortgage } \\
\text { interest payment }\end{array}$ & $\begin{array}{c}-0.008 \\
(0.004)\end{array}$ & $\begin{array}{l}-0.002 \\
(0.009)\end{array}$ & \\
\hline Rental subsidies dummy & $\begin{array}{l}-0.106^{*} \\
(0.049)\end{array}$ & $\begin{array}{l}-0.315^{*} \\
(0.134)\end{array}$ & \\
\hline Age 19-24 & $\begin{array}{l}0.729^{*} \\
(0.055)\end{array}$ & $\begin{array}{l}0.294^{*} \\
(0.136)\end{array}$ & $\begin{array}{l}-1.959^{*} \\
(0.213)\end{array}$ \\
\hline Age $25-29$ & $\begin{array}{l}0.435^{*} \\
(0.045)\end{array}$ & $\begin{array}{c}0.149 \\
(0.113)\end{array}$ & $\begin{array}{l}-1.705^{*} \\
(0.194)\end{array}$ \\
\hline Age 30-39 & $\begin{array}{l}0.128^{*} \\
(0.035)\end{array}$ & $\begin{array}{c}0.151 \\
(0.088)\end{array}$ & $\begin{array}{l}-0.274^{*} \\
(0.136)\end{array}$ \\
\hline Age $50+$ & $\begin{array}{l}-0.275^{*} \\
(0.048)\end{array}$ & $\begin{array}{l}-0.234^{*} \\
(0.117)\end{array}$ & $\begin{array}{l}-0.417^{*} \\
(0.209)\end{array}$ \\
\hline Female & $\begin{array}{l}0.101^{*} \\
(0.039)\end{array}$ & $\begin{array}{l}-0.062 \\
(0.091)\end{array}$ & $\begin{array}{l}0.359^{*} \\
(0.157)\end{array}$ \\
\hline Household with children & $\begin{array}{l}0.070 \\
(0.047)\end{array}$ & $\begin{array}{l}-0.297^{*} \\
(0.120)\end{array}$ & $\begin{array}{l}0.399^{*} \\
(0.177)\end{array}$ \\
\hline Two adults household & $\begin{array}{l}0.003 \\
(0.040)\end{array}$ & $\begin{array}{l}0.229^{*} \\
(0.094)\end{array}$ & $\begin{array}{l}3.058^{*} \\
(0.207)\end{array}$ \\
\hline Female X children & $\begin{array}{c}-0.249^{*} \\
(0.058)\end{array}$ & $\begin{array}{l}-0.318^{*} \\
(0.147)\end{array}$ & $\begin{array}{l}0.454^{*} \\
(0.221)\end{array}$ \\
\hline Large city & $\begin{array}{l}-0.029 \\
(0.045)\end{array}$ & $\begin{array}{l}-0.279^{*} \\
(0.107)\end{array}$ & $\begin{array}{l}-1.570^{*} \\
(0.162)\end{array}$ \\
\hline Native Dutch & $\begin{array}{l}0.098^{*} \\
(0.034) \\
\end{array}$ & $\begin{array}{l}0.296^{*} \\
(0.085) \\
\end{array}$ & $\begin{array}{l}2.535^{*} \\
(0.182) \\
\end{array}$ \\
\hline \multicolumn{4}{|l|}{ Baseline Hazard } \\
\hline $0-45$ days & $\begin{array}{l}1.887^{*} \\
(0.165)\end{array}$ & $\begin{array}{l}0.715^{*} \\
(0.166)\end{array}$ & \\
\hline 46-91 days & $\begin{array}{l}2.487^{*} \\
(0.224)\end{array}$ & $\begin{array}{l}0.975^{*} \\
(0.223)\end{array}$ & \\
\hline $92-182$ days & $\begin{array}{l}3.097^{*} \\
(0.296)\end{array}$ & $\begin{array}{l}1.018^{*} \\
(0.232)\end{array}$ & \\
\hline $183-730$ days & $\begin{array}{l}2.229^{*} \\
(0.232) \\
\end{array}$ & $\begin{array}{l}0.558^{*} \\
(0.136) \\
\end{array}$ & \\
\hline$v_{h, 1}$ & $\begin{array}{c}-0.084 \\
(0.193)\end{array}$ & $P\left(v_{h, 1}, v_{l, 1}, v_{n, 1}\right)$ & $\begin{array}{c}0.030 \\
(0.035)\end{array}$ \\
\hline$v_{h, 2}$ & $\begin{array}{l}-6.728^{*} \\
(0.339)\end{array}$ & $P\left(v_{h, 1}, v_{l, 1}, v_{n, 2}\right)$ & $\begin{array}{c}0.025 \\
(0.025)\end{array}$ \\
\hline$v_{l, 2}$ & $\begin{array}{c}-1.026^{*} \\
(0.062)\end{array}$ & $P\left(v_{h, 1}, v_{l, 2}, v_{n, 1}\right)$ & $\begin{array}{l}0.175^{*} \\
(0.030)\end{array}$ \\
\hline$v_{n, 2}$ & $\begin{array}{c}-2.502^{*} \\
(0.380)\end{array}$ & $P\left(v_{h, 1}, v_{l, 2}, v_{n, 2}\right)$ & $\begin{array}{l}0.084^{*} \\
(0.026)\end{array}$ \\
\hline $\operatorname{corr}\left(v_{h}, v_{l}\right)$ & $\begin{array}{c}0.055 \\
(0.102)\end{array}$ & $P\left(v_{h, 2}, v_{l, 1}, v_{n, 1}\right)$ & $\begin{array}{l}0.251^{*} \\
(0.035)\end{array}$ \\
\hline $\operatorname{corr}\left(v_{h}, v_{n}\right)$ & $\begin{array}{c}0.133 \\
(0.096)\end{array}$ & $P\left(v_{h, 2}, v_{l, 1}, v_{n, 2}\right)$ & $\begin{array}{l}0.178^{*} \\
(0.034)\end{array}$ \\
\hline $\operatorname{corr}\left(v_{l}, v_{n}\right)$ & $\begin{array}{l}-0.362^{*} \\
(0.136)\end{array}$ & $P\left(v_{h, 2}, v_{l, 2}, v_{n, 1}\right)$ & $\begin{array}{l}0.096^{*} \\
(0.030)\end{array}$ \\
\hline Log likelihood & $-11,639$ & $P\left(v_{h, 2}, v_{l, 2}, v_{n, 2}\right)$ & $\begin{array}{l}0.159^{*} \\
(0.033)\end{array}$ \\
\hline
\end{tabular}

* indicates significance at the $5 \%$ level.

The standard error of the correlation terms were calculated as in Table 2. 


\section{Conclusion}

In this paper we have offered a new contribution to understanding the relationship between the housing and labour market by addressing the role of commutes and housing costs, in contrast to earlier literature which often focused on the role of housing mobility. In accordance with some earlier studies based on European data, we used an extensive and unique database from the Netherlands and found that residential mobility associated with unemployment is very small and cannot be expected to have an impact on aggregate unemployment rates. What we also found, however, is that there is a sizeable impact of housing cost on the exit rate from unemployment. Our theoretical analysis suggests that housing costs have a positive impact on the exit rate from unemployment when workers have decreasing absolute risk aversion, which we regard as a plausible characteristic. Our empirical analysis confirms this prediction. Although home ownership in itself has a strongly negative impact on the exit rate to non-local jobs, high mortgage payments have a substantial positive impact on both exit rates, making the net effect of ownership and mortgage positive in the local labour market and negative in the non-local one. Similarly, rent subsidies have a significant negative impact on both exit rates, and especially on non-local jobs.

The negative effect of homeownership on acceptance of non-local job is not predicted by our theoretical model. However, a negative net effect is only present for outright owners or those with a small mortgage left. These are often elder or very wealthy people. Another surprising finding is that the partner's leverage has a negative impact on the individual nonlocal labour market performance. We have suggested that a plausible explanation is that the prime earner in a household is typically the one from whose income the mortgage payments are deducted. Therefore, an individual with a leveraged partner is often the secondary earner, and hence is likely to exhibit inferior labour performance. This division is displayed in Table 4, which provides descriptive statistics on the yearly gross income of individuals in two-adult households, based on the data of the IPO database.

Our results are somewhat more favourable to Oswald's thesis than earlier micro studies as they can be interpreted as implying that the thesis holds for outright owners as well as secondary workers in two-earner households, both groups having lower exit rates from unemployment. Nevertheless, our results confirm the findings of these earlier studies in that we find that the large group of leveraged main earners have higher exit rates from unemployment than otherwise comparable renters. 
Table 4. Yearly gross income of partners in two-adult households

\begin{tabular}{|cl|rr|rr|}
\hline & \multicolumn{2}{|c|}{$\begin{array}{c}\text { Individual is } \\
\text { unleveraged }\end{array}$} & \multicolumn{2}{|c|}{$\begin{array}{c}\text { Individual is } \\
\text { leveraged }\end{array}$} \\
& & Mean & Std. Err & Mean & Std. Err \\
\hline Partner is & \# of households & 1,139 & & 2,480 & \\
unleveraged & Individual's Income & 24,232 & 17,334 & 50,871 & 32,799 \\
& Partner's Income & 2,555 & 10,451 & 14,254 & 15,728 \\
\hline Partner is & \# of households & 2,113 & & 71 & 27,734 \\
leveraged & Individual's Income & 22,779 & 16,674 & 50,447 & 31,854 \\
& Partner's Income & 59,923 & 46,555 & 49,297 & \\
\hline
\end{tabular}

A potentially important suggestion of this analysis is that financing owner-occupied housing through large mortgages, as is common in the Netherlands, may have strong positive effects on labour market performance. Total mortgage debt in the Netherlands currently exceeds GDP which is exceptional. Our analysis suggests that this may have a relationship with the surprisingly strong performance of the Dutch labour market following the 2008 crisis as well as with the long average commutes of Dutch workers. Our analysis, therefore, sheds a somewhat different light on the relationship between Dutch labour market and housing policy than is presented in, for instance, OECD's Economic Survey for the Netherlands 2010, which emphasizes the negative impacts of long commutes and large mortgage loans.

\section{References}

Battu, H., A. Ma and E. Phimister (2008), Housing Tenure, Job Mobility and Unemployment in the UK. Economic Journal, 118, 311-328.

Chiappori, P.A. and M. Paiella (2008), Relative Risk Aversion is Constant: Evidence from

Panel Data. http://ideas.repec.org/s/prt/dpaper.html 5, Department of Economic Studies, University of Naples "Parthenope", Italy.

Coulson, N.E., and L.M. Fisher (2009), Housing Tenure and Labour Market Impacts, Journal of Urban Economics, 65, 252-264.

Flatau, P., M. Forbes, P.H. Hendershott and G. Wood (2003), Homeownership and Unemployment: The Roles of Leverage and Public Housing. NBER working paper 10021.

Gollier, C. (2001) The Economics of Risk and Time. MIT Press, Cambridge, Mass.

Green, R. And P. Hendershott (2001), Homeownership and Unemployment in the US, Urban Studies, 38, $1501-1520$.

Munch, J.R., M. Rosholm and M. Svarer (2006) Are Home Owners Really More Unemployed? Economic Journal, 116, 991-1013. 
Rouwendal, J. (1999), Spatial Job Search and Commuting Distances, Regional Science and Urban Economics, 29, 491-517.

Rouwendal, J. and P. Nijkamp (2010) Homeownership and Labour-market Behaviour: Interpreting the Evidence. Environment and Planning A, 42, 419-433.

Oswald, A.J. (1996), A Conjecture on the Explanation for High Unemployment in the Industrialized Nations: Part I, Working Paper 475, Dept. of Economics, University of Warwick, Coventry.

Oswald, A. (1997), Thoughts on Nairu, Journal of Economic Perspectives, 11, 1, 227-228.

Oswald, A. J. (1999), The Housing market and Europe's Unemployment: A Non-Technical Paper. Working paper, available at: http://www2.warwick.ac.uk/fac/soc/economics/staff/academic/oswald/homesnt.pdf.

Svarer, M., M. Rosholm and J.R. Munch (2005), Rent Control and Unemployment Duration, Journal of Public Economics, 89, 2165-2181.

Van den Berg, G.J., and C. Gorter (1997), Job Search and commuting Time, Journal of Business and Economic Statistics, 15, 2, 269-281.

Van Leuvensteijn M. and P. Koning (2004), The Effect of Home-ownership on Labour Mobility in the Netherlands, Journal of Urban Economics, 55, 580-596.

Van Ommeren, J., P. Rietveld and P. Nijkamp (2000), Job Mobility, Residential Mobility and Commuting, Annals of Regional Science, 34, 213-232.

Van Vuuren, A. (2008), The Relationship between Expectations of Labour Market Status, Homeownership and the Duration of Unemployment, EEA Working paper, online available at: http://www.eea-esem.com/files/papers/EEA-ESEM/2007/1916/housing.pdf. 


\section{Appendix: The effect of housing cost on the reservation wage}

It follows from (4) that a change in housing cost will increase the reservation wage if:

$$
u_{1}^{\prime}\left(y^{r e s}-p(h)\right)<\frac{\rho u_{1}(b-p(h))+\lambda \int_{y>y^{r e s}} u_{1}(y-p(h)) f(y) d y}{\rho+\lambda \int_{y>y} \text { res }_{1} f(y) d y}
$$

To relate this to the property of decreasing absolute risk aversion, it is useful to observe that one can reinterpret equation (4) as a comparison of the utility of a certain income $y^{\text {res }}-p(h)$ to the expected value of uncertain incomes. The uncertain income has a probability distribution that is partly discrete and partly continuous. It equals $b-p(h)$ with probability $\rho /\left(\rho+\lambda \int_{y>y^{r e s}} f(y) d y\right)$, and $y$ with probability density $\lambda f(y) /\left(\rho+\lambda \int_{y>y^{r e s}} f(y) d y\right)$.

If the certain income increases by less than the expected value of the uncertain income when wealth increases, inequality (A1) is valid. This is the case if the utility satisfies a property that is known as decreasing absolute risk aversion, see for instance Gollier (2001, p. 24).

It follows than that, in the context of the present paper, inequality (A1) holds if the job seeker's utility function has the same property. 